PASQUALE TREMATERRA $(*)\left(^{\circ}\right)$ - STEFANO SCALERCIO $(* *)$ - MARCO COLACCI $(*)$

\title{
THAUMETOPOEA HELLENICA SP. N. AND THAUMETOPOEA MEDITERRANEA SP. N. NEW TAXA FROM SOUTHERN EUROPE (LEPIDOPTERA NOTODONTIDAE THAUMETOPOEINAE)
}

\author{
(*) Department of Agriculture, Environmental and Food Sciences, University of Molise, Campobasso, Italy \\ (**) Consiglio per la Ricerca in Agricoltura e l'analisi dell'Economia Agraria, Unità di Ricerca per la Selvicoltura in \\ Ambiente Mediterraneo, Rende, Italy \\ $\left(^{\circ}\right)$ Corresponding author: trema@unimol.it
}

\begin{abstract}
Trematerra P., Scalercio S., Colacci M. - Thaumetopoea hellenica sp. n. and Thaumetopoea mediterranea sp. n. new taxa from southern Europe (Lepidoptera Notodontidae Thaumetopoeinae)

Two new species of Lepidoptera of the genus Thaumetopoea Hübner, 1820, T. hellenica sp. n. Trematerra and Scalercio and T. mediterranea sp. n. Trematerra and Scalercio are described. The adults of T. hellenica were collected from two localities in Greece: Magnessia (Thessaly) and Kifissia, Ktima Syggrou (Athens). Adults of T. mediterranea were collected from the Island of Pantelleria (Trapani, Italy). By comparison of the morphological characters (genitalia and canthus of males) and the results of genetic analysis (DNA barcoding) it was found that the material from Greece and from Pantelleria Island are different from Thaumetopoea pityocampa (Den. and Schiff.) collected from Italy and Spain. This same material of the new species is also different from all the species of the genus.
\end{abstract}

Key Words: Thaumetopoea hellenica, Thaumetopoea mediterranea, new species, Greece, Italy.

\section{INTRODUCTION}

Following AGENJo (1941) and KIRIAKOFF (1970) the genus Thaumetopoea Hübner, 1820, sensu lato includes a dozen species in the Palaearctic region, and one in the Afrotropical region. De FreINA and WitT (1982) split it into two genera, Thaumetopoea Hübner sensu stricto and Traumatocampa Wallengren, 1871, with a further separation of the new genus Heliantocampa de Freina and Witt, 1985, from Traumatocampa using morphological characters of the adults (mainly frontal process of males "canthus") (DE FREINA and WITT, 1987). According to these authors, Thaumetopoea processionea (Linnaeus, 1758) and T. solitaria (Freyer, 1838) belong to the genus Thaumetopoea, while all the other species are grouped in Traumatocampa [T. apologetica Strand, 1909, T. bonjeani (Powell, 1922), T. cheela Moore, 1883, T. dhofarensis (Wiltshire, 1980), T. jordana (Staudinger, 1894), T. libanotica Kiriakoff and Talhouk, 1975, T. pinivora (Treitschke, 1834), T. pityocampa (Denis and Schiffermüller, 1755), T. wilkinsoni (Tams, 1925)], only one taxon was assigned to the genus Helianthocampa $[H$. herculeana (Rambur, 1840)]. Three species described later from Turkey were reported in the genus Traumatocampa, namely T. ispartaensis Doganlar and Avci, 2001, T. sedirica M. Doganlar, 2005 and T. torosica M. Doganlar, 2005 (KIRIAKOFF and TalHouK, 1975; Doganlar and AvCI, 2001; DOGANLAR et al., 2005).

Genetic analysis of the T. pityocampa - T. wilkinsoni group (SAlvato et al., 2002; Simonato et al., 2007; KERDELHUÉ et al., 2009), indicates that the group actually consists of three species with a different geographic distribution. T. pityocampa is present in Europe and northwestern Africa, T. wilkinsoni lives in the Middle East, and a new clade provisionally called $T$. pityocampa ENA (Eastern-North Africa) occurs between Libya and eastern
Algeria (Simonato et al., 2013). Molecular phylogenies support a parallel evolution of the morphological traits used to separate Thaumetopoea in the three distinct genera Traumatocampa, Heliantocampa and Thaumetopoea sensu stricto. This result suggests that all species should be treated as members of a single genus Thaumetopoea sensu lato. The genetic comparisons corroborate results initially obtained by KERDELHUÉ et al. (2009) and favour the status of distinct species for T. pityocampa ENA, which should be separated from T. pityocampa.

These differences are not apparent in the morphological characters. There is a need for identifying new morphological synapomorphies that support the three identified clades, as those characters more commonly used (presence of the canthus on the front of the adult, the spine on the foreleg tibia and the size of the egg scales) show evidence of convergent evolution (DÉMOLIN, 1969; Milani, 1990; Simonato et al., 2013; Roques, 2015; Mokhefi et al., 2016). A new taxon was recently described from Yemen as Thaumetopoea loxostigma (HACKER, 2016).

With the aim to provide a contribution to the knowledge of this group of Lepidoptera we report the results obtained during the study of the morphological and genetic characters of male specimens belonging to Thaumetopoea spp. that we collected during 2010-2016 in Greece, Italy and Spain.

\section{MATERIAL AND METHODS}

The adults of Thaumetopoea spp. studied were mostly found in pheromone traps baited with lures containing $1 \mathrm{mg}$ of the synthetic sex pheromone component $(Z)-13$ hexadecen-11-ynyl acetate positioned in four urban and recreational places in Greece, Italy and Spain (see also LIFE 
PISA project 2014-2017, www.lifepisa.eu). Several specimens from Greece and southern Italy were collected using light traps in order to increase the studied material and to improve the taxonomy of mountain populations of $T$. pityocampa in that geographic area. The use of light traps allowed us to collect and study also some females which were absent in pheromone traps.

Localities investigated using pheromone traps were: Greece [Goritsa, Volos (Thessaly); Ktima Syggrou, Kifissia (Attica)]; Italy [Campitello Matese, San Massimo (Campobasso), Molise; San Giovannello, Campobasso (Campobasso), Molise; Marinelle, Petacciato (Campobasso), Molise; Khaddiuggia, Pantelleria Island (Trapani), Sicily]; Spain [Serra, Porta Coeli (Valencia)].

Localities investigated by light traps were: Greece [Goritsa, Volos (Thessaly)]; Italy [Diga del Menta, Aspromonte (Reggio Calabria), Calabria; Glicarello, Montalto Uffugo (Cosenza), Calabria; Mangiatoie, Massiccio della Sila (Cosenza), Calabria; Palmento, Serra San Bruno (Vibo Valentia), Calabria; Quaresima, Aprigliano (Cosenza), Calabria; Rosarella, Serra San Bruno (Vibo Valentia), Calabria; San Bernardo, Massiccio della Sila (Cosenza), Calabria; Vallone Argentino, Montalto Uffugo (Cosenza), Calabria].

\section{DNA BARCODING ANALYSES}

Eleven specimens were submitted to DNA barcoding: four from Greece, five from Italy and two from Spain (Table 1). Voucher material is stored at the University of Molise, Department of Agricultural, Environmental and Food Sciences, Campobasso (Italy).

A small piece of a leg was transferred to a lysis plate under ca $0.3 \mathrm{ml} 100 \%$ alcohol. Tissue samples were submitted to the standard procedures of the Canadian Centre for DNA Barcoding (CCDB) and of the University of Milano (Italy) for sequencing the mitochondrial 5' cytochrome oxidase gene, subunit 1 (COI), the standard marker for the identification of most animals. LepF1 and LepR1 were the primers used for PCR and sequencing (HAJIBABAEI et al., 2006). Sequences were blasted against the complete sequence database of BOLD data systems (RATNASINGHAM and HEBERT, 2007) in order to investigate the closest matches using the BOLD Identification Engine (http://www.boldsystems.org/index.php/ IDS_OpenIdEngine). Sequences having no matches on BOLD were blasted against the complete sequence database of GenBank (HAJiBABEI et al., 2006; RATNASINGHAM and HeBERT, 2007). Genetic distances between sequences were measured using minimum pairwise distance and Neighbour joining tree was built using Kimura 2-parameter distance model for COI-5P marker, both obtained by using BOLD functions.

\section{Thaumetopoea hellenica sp. $\mathrm{n}$. Trematerra and Scalercio}

MATERIAL EXAMINED - Holotype, 1 male, Goritsa, $180 \mathrm{~m}$ a.s.1., Magnesia, Thessaly, Greece (Lat $39.352447^{\circ}$, Lon 22.974072 ${ }^{\circ}$ ), 10.X.2015, legit Anastasia Nikolaidou (Collection Trematerra, Campobasso, Italy).

Paratypes, 1 male, Goritsa, $180 \mathrm{~m}$ a.s.l., Magnesia, Thessaly, Greece (Lat 39.352447, Lon 22.974072 ${ }^{\circ}$ ), 10.X.2015, legit Anastasia Nikolaidou; 2 males, Kifissia, Ktima Syggrou (Athens, Greece) $230 \mathrm{~m}$ a.s.1. (Lat $38.061713^{\circ}$, Lon $23.815891^{\circ}$ ), 10.IX.2015, legit Maria Boukouvala (Collection Trematerra, Campobasso, Italy).

Three males Goritsa, $50 \mathrm{~m}$ a.s.l., Magnesia, Thessaly, Greece (Lat $39.352447^{\circ}$, Lon $22.974072^{\circ}$ ), 5.IX.2016, legit
Marco Colacci; 1 female, Goritsa $50 \mathrm{~m}$ a.s.1., Magnesia, Thessaly, Greece (Lat 39.352447 ${ }^{\circ}$, Lon $22.974072^{\circ}$ ), 5.IX.2016, legit Marco Colacci (Collection Trematerra, Campobasso, Italy).

DESCRIPTION - Adult (Fig. I, 1). Wing-span of male 30$35 \mathrm{~mm}$, the female is larger, with a wingspan of $43 \mathrm{~mm}$. Scales on scapus and front are light brown-greyish; thorax brown-grey to light brown, with two lateral greyish spots. The abdomen of male is light honey-brown, brushy and sharp; in the female it is stout and its last segments are covered with a tuft of scales. The antennae are yellowgreyish from the base to the tip, appearing bipectinate. Forewing whitish-grey with three dark-brown transverse bands: basal band small, median band interrupted in the middle and more evident in basal margin, distal band completely darker near costal margin; discocellular spot fairly vague, half-moon shaped, light brown-greyish in colour. Distal spot at apex of wing brown-greyish. Costal area brownish-grey. Cilia brown to light-brown, rather concolorous with markings, brown in basal part, alternate to whitish groups. Wing veins dark-brown. Hindwings whitish-creamy with vague anal spot; anal margin with a brownish thin band; fringes withish-creamy. Tuft of hairs, light brown-creamy on internal margin.

Male Genitalia (Fig. I, 2 and Fig. II, 1-5) - Uncus developed, slightly curved, projected forward, its top with two small thorns; socii broad, sub-triangular, twice as long as its width, sickle-shaped (Fig. II, 1). Tegumen broad, constricting towards the apex. Valva sub-triangular, elongated, about twice as long as its width, costal margin rather straight slightly concaved at apex; cucullus rounded; ventral edge of valva and sacculus rounded (Fig. II, 3 and 5). Juxta sub-rectangular, longer than wide, proximal margin hollowed, distal margin rounded (Fig. II, 2). Saccus rather long (Fig. I, 2). Aedeagus amphora-shaped, longer than valva, slender, narrow at the distal part; vesica tapering, coecum penis enlarged (Fig. II, 4).

FRONTAL PROCESS OF MALES - Frontal process (canthus) of males of $T$. hellenica is reported in figure III, 1. It has five teeth, one long and four small, and of these the first one is quite pronounced. In frontal view, the bottom four have a different shape. In dorsal part of the canthus a developed projection is present.

DNA BARCODING ANALYSES - The distance of the $T$. hellenica BIN from the nearest neighbour (NN) is equal to $3.05 \%$. The $\mathrm{NN}$ is the BIN including the sequence deposited in GenBank (accession number HE963113.1) belonging to the ENA clade of SiMONATO et al. (2013) and the sequence of the holotype of the new species T. mediterranea. The distance from the nearest sequence of $T$. pityocampa deposited in GenBank is quite higher being equal to $7 \%$ (Table 1 and Fig. IV).

DistRIBUTION - Known for Magnesia (Thessaly, Greece) and Ktima Syggrou, Kifissia (Athens, Greece).

BIOLOGY - Moths were collected with funnel pheromone traps and light traps during September-October. Food plant: we observed larvae on Pinus halepensis Miller (Fig. V, 1).

Etymology - The name of the new species Thaumetopoea hellenica refers to its distribution (hellenicus, -a, $\mathrm{um}=$ Greek) 

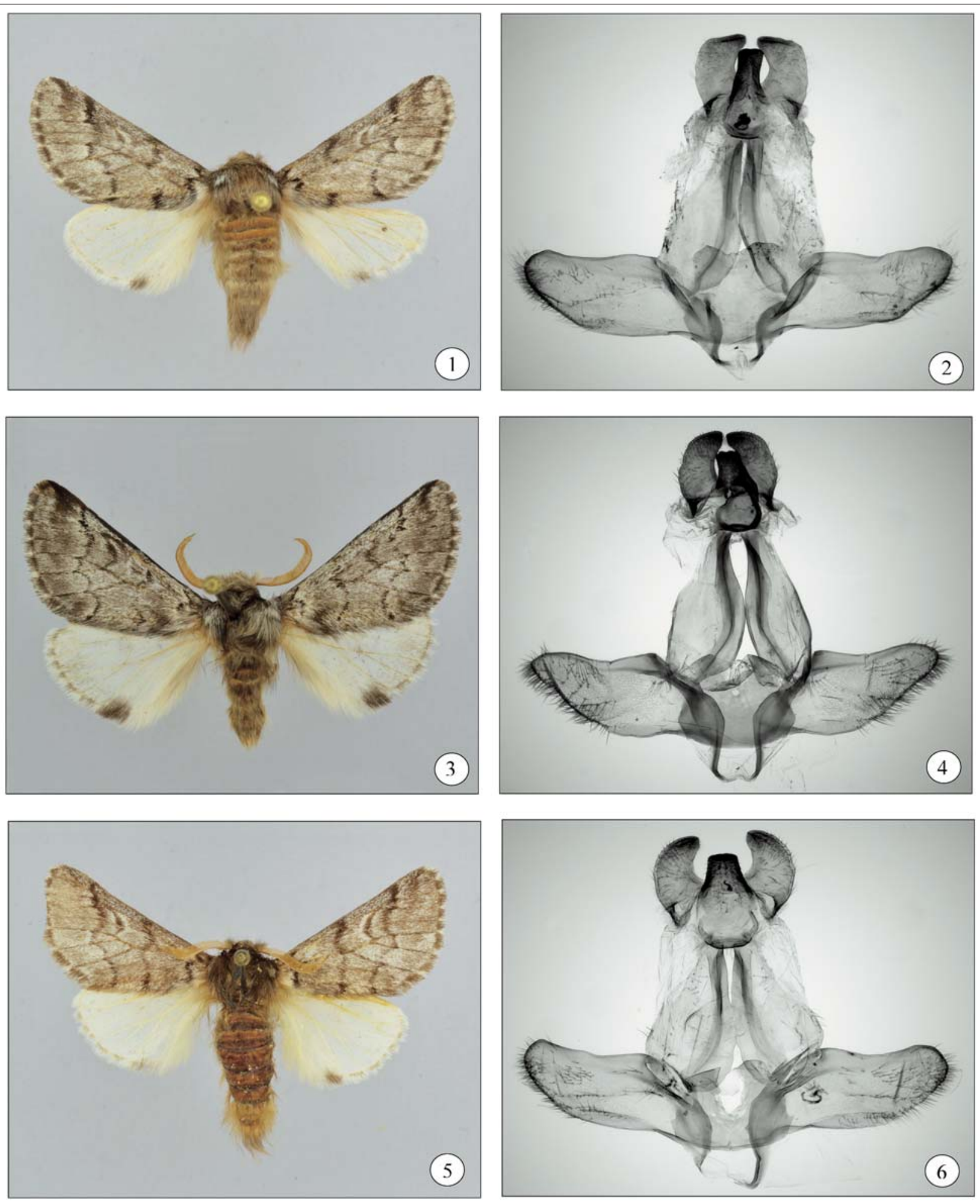

Fig. I - Thaumetopoea hellenica sp. n.: adult (1); male genitalia (2). Thaumetopoea mediterranea sp. n.: adult (3); male genitalia (4). Thaumetopoea pityocampa (Den. and Shiff.): adult (5); male genitalia (6).

\section{Thaumetopoea mediterranea sp. $\mathrm{n}$.}

Trematerra and Scalercio

Material examined - Holotype, 1 male, Pantelleria Island (Trapani, Italy) $120 \mathrm{~m}$ a.s.1., Khaddiuggia (Lat $36.822769^{\circ}$, Long $\left.11.974918^{\circ}\right)$, 18.VIII.2016, legit Pasquale Trematerra (Collection Trematerra, Campobasso, Italy).
Paratype, 1 male, Pantelleria Island (Trapani, Italy) $120 \mathrm{~m}$ a.s.1., Khaddiuggia (Lat $36.822769^{\circ}$, Long $11.974918^{\circ}$ ), 18.VIII.2016, legit Pasquale Trematerra (Collection Trematerra, Campobasso, Italy).

DESCRIPTION - Adult (Fig. I, 3). Wing-span of male 30-35 $\mathrm{mm}$. Scales on scapus and frons, light brown; thorax blackish-brown to light-brown, with two lateral light- 

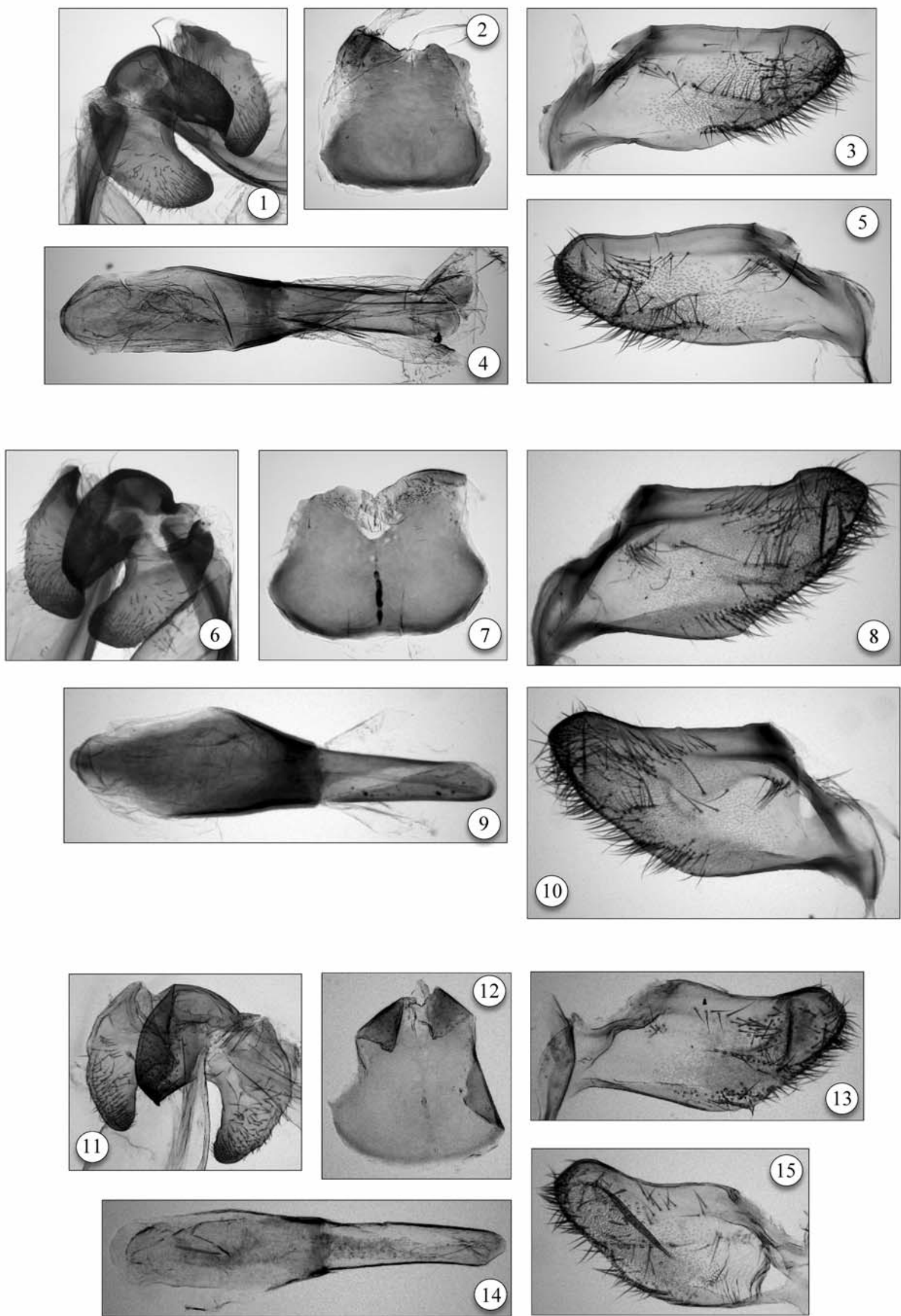

Fig. II - Male genitalia details of Thaumetopoea hellenica sp. n. (1-5): uncus (1); juxta (2); right valva (3); aedeagus (4); left valva (5). Thaumetopoea mediterranea sp. n. (6-10): uncus (6); juxta (7); right valva (8); aedeagus (9); left valva (10). Thaumetopoea pityocampa (Den. and Shiff.) (11-15): uncus (11); juxta (12); right valva (13); aedeagus (14); left valva (15). 

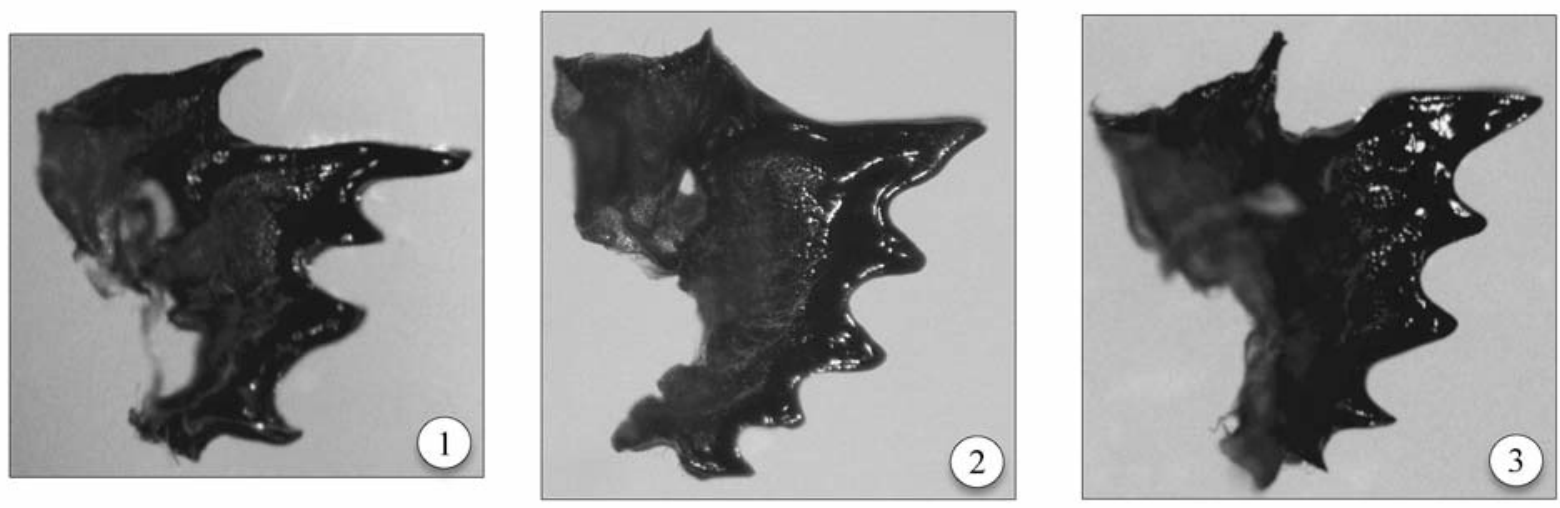

Fig. III - Frontal process of males (canthus): Thaumetopoea hellenica sp. n. (1); Thaumetopoea mediterranea sp. n. (2); Thaumetopoea pityocampa (Den. and Shiff.) (3).

Table 1 - Specimens of Thaumetopoea submitted to DNA barcoding.

\begin{tabular}{|c|c|c|c|c|c|}
\hline \hline Species & Sample ID & $\begin{array}{c}\text { Fragment } \\
\text { length }\end{array}$ & BIN & Country & Locality \\
\hline T. hellenica & LEP-SS-00414 & 534 & BOLD : ADB8365 & Greece & Kifissia \\
\hline T. hellenica & LEP-SS-00415 & 658 & BOLD : ADB8365 & Greece & Volos \\
\hline T. hellenica & LEP-SS-00416 & 629 & BOLD : ADB8365 & Greece & Volos \\
\hline T. hellenica & LEP-SS-00417 & 658 & BOLD : ADB8365 & Greece & Kifissia \\
\hline T. pityocampa & LEP-SS-00418 & 639 & BOLD : AAK2887 & Spain & Valencia \\
\hline T. pityocampa & LEP-SS-00420 & 614 & BOLD : AAK2887 & Spain & Valencia \\
\hline T. pityocampa & LEP-SS-00419 & 639 & BOLD : AAK2887 & Italy & Petacciato \\
\hline T. pityocampa & LEP-SS-00421 & 658 & BOLD : AAK2887 & Italy & Petacciato \\
\hline T. pityocampa & LEP-SS-00457 & 658 & BOLD : AAK2887 & Italy & Campitello \\
\hline T. pityocampa & LEP-SS-00466 & 638 & BOLD : ADF2067 & Italy & Quaresima \\
\hline T. mediterranea & LEP-SS-00451 & 658 & BOLD : ACH8435 & Italy & Pantelleria \\
\hline
\end{tabular}

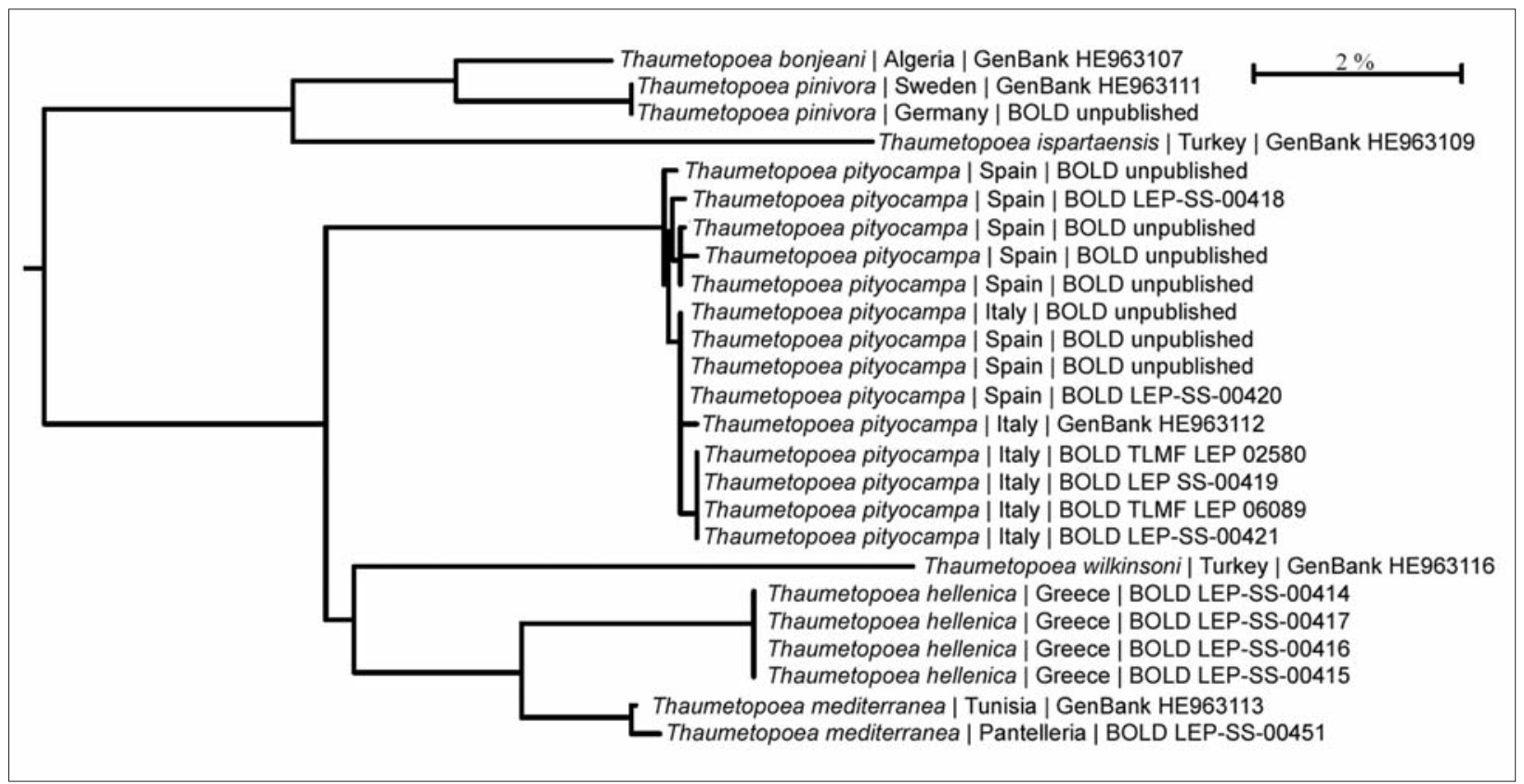

Fig. IV - Neighbour joining tree (Kimura 2-parameter distance model for COI-5P marker) for 25 Thaumetopoea specimens belonging to 7 species. Terminals with taxonomy, geography, sequence repositories and IDs of published sequences. 


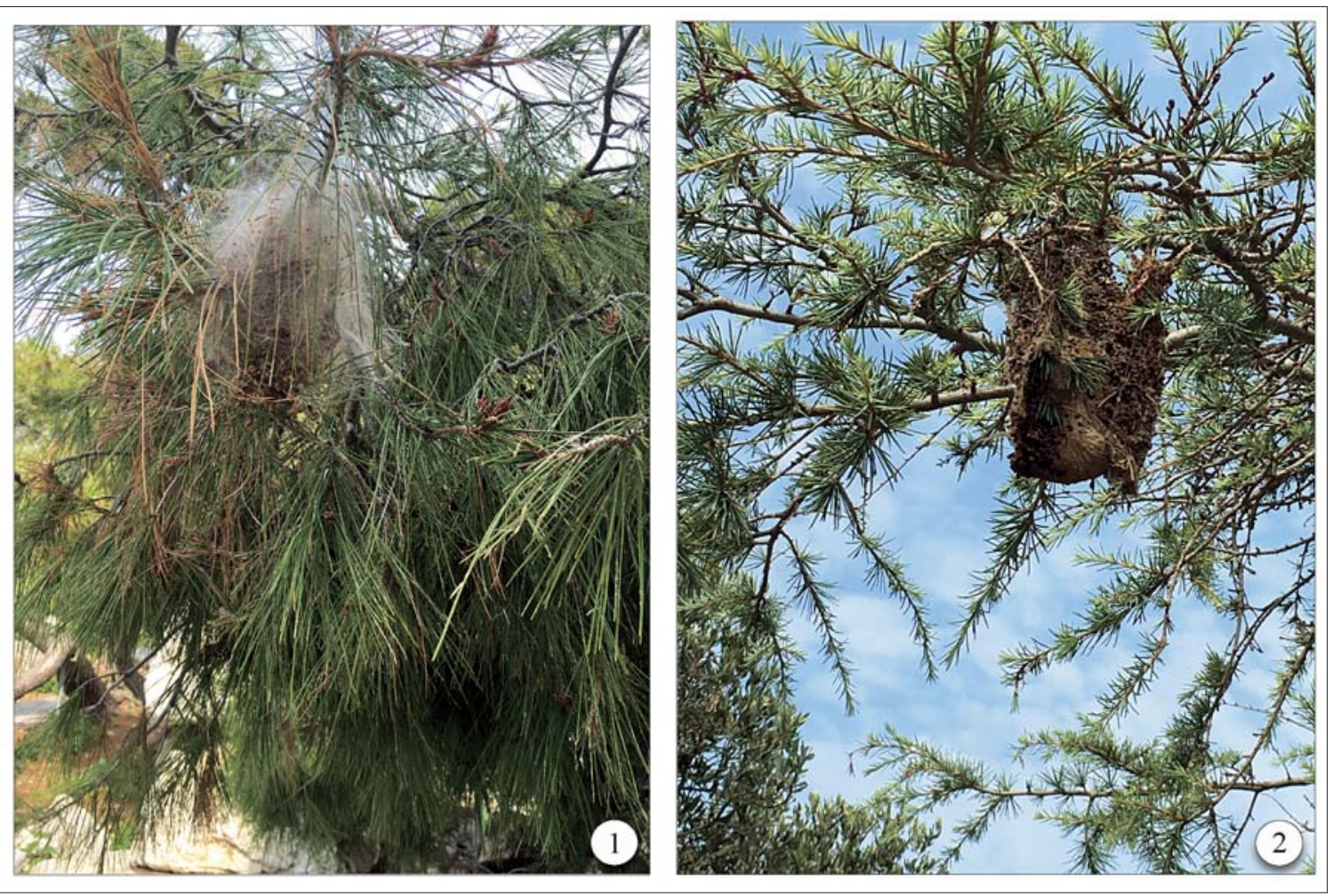

Fig. V - Winter nests of Thaumetopoea hellenica sp. n. (1) and Thaumetopoea mediterranea sp. n. (2).

coloured tufts; the abdomen is brushy and sharp, blackishbrown with light brown scales. Antennae bipectinate, light brown from the base to the tip. Forewings ground colour whitish-grey with three blackish transverse narrow bands: basal band small, median band complete, distal band complete, darker near costal and anal margins; discocellular spot evident, dark-brown/black, arrow shaped. Spot between basal band and median bands evident. Distal spot at apex of wing blackish-brown. Distal part of wings suffused with dark brown and black scales. Costal margin black, costal area blackish. Cilia dark-brown, rather concolorous with markings, alternate with whitish cilia. Wing veins dark-brown. Hindwings whitish-creamy, suffused brownish in distal margin, evident black anal spot; anal margin with a blackish band; fringes withish-creamy, blackish at base. Wing veins honey-coloured. Long tuft of hairs, light brown-creamy internal margin.

Male genitalia (Fig. I, 4 and Fig. II, 6-10) - Uncus developed, slightly rounded, projecting forward, its top with two thorns; socii broad, sub-trapezoidal, longer than wide (Fig. II, 6). Tegumen broad, constricting towards the apex. Valva subtrapezoidal, elongated, half as long as broad, costal margin rather straight, slightly concave at the apex; cucullus slightly rounded; ventral edge of valva and sacculus rounded with an angle (Fig. II, 8 and 10). Juxta sub-rectangular, wider than long, proximal margin concave, distal margin rounded (Fig. II, 7). Saccus rather long (Fig. I, 4). Aedeagus longer than valva, slender, narrow in the distal part; vesica tapering coecum penis enlarged (Fig. II, 9).

FRONTAL PROCESS OF MALES - Frontal process of males (canthus) of $T$. mediterranea is reported in figure III, 2. Front with a process having distinctive appearance. It has five teeth, one long and four small all similarly shaped, in frontal view. A small projection is present on dorsal part of the canthus.

DNA BARCODING ANALYSES - The distance of the $T$. mediterranea BIN from the nearest neighbour $(\mathrm{NN})$ is equal to $3.05 \%$. The NN is represented by the BIN of the new species $T$. hellenica. The distance from the nearest sequence of T. pityocampa deposited in GenBank is equal to $6 \%$. The sequence of the holotype of the new species $T$. mediterranea is identic to the sequence deposited in GenBank (accession number HE963113.1) belonging to the ENA clade of SimONato et al. (2013) (Table 1 and Fig. IV).

DistribUTION - Known for the locus typicus: Pantelleria Island (Trapani, Italy); the "ENA clade" is distributed from Libya to eastern Algeria.

BIOLOGY - Moths collected with funnel pheromone traps in late August. Food plant: we observed larvae on Cedrus spp. (Fig. V, 2).

Etymology - The name refers to the Mediterranean Sea area.

\section{DIAGNOSIS}

As reported, T. pityocampa, T. hellenica and $T$. mediterranea show considerable genetic differences. Morphologically the three taxa resemble each other, they can be differentiated by wing pattern and shape of the canthus, and in male genitalia by the shape of socii, valvae and juxta (Fig. I, 2, 4 and 6).

When comparing the wing pattern of the three species it 
is possible to note that in T. mediterranea it is more marked and evident, blackish coloured, with bigger anal spot on hindwings. Discocellular spot of T. pityocampa is closer to the distal band than in the other two species. Transverse bands are more slender in T. mediterranea. The median band is interrupted in T. hellenica and complete in T. mediterranea and T. pityocampa (Fig. I, 1, 3 and 5).

The uncus of T. mediterranea is longer than the socii; socii in T. mediterranea are sub-triangular, longer than wide and ear-shaped; in T. pityocampa the socii are broad, half-moon shaped or even semi-circular. Valva elongated and narrow in $T$. hellenica. Compared to $T$. pityocampa valva in T. mediterranea is larger. Aedeagus is larger and broader in $T$. mediterranea than in $T$. hellenica and $T$. pityocampa. Shape of juxta is sub-rectangular, longer than wide in T. hellenica. It is sub-rectangular, wider than long in $T$. mediterranea, the juxta of $T$. pityocampa is hexagonal, as long as broad. Proximal of juxta is concave in T. hellenica and T. mediterranea, less in T. pityocampa. It is shield-shaped, with proximal margin stretching to the angles in T. pityocampa and T. hellenica (Fig. II, 1-15).

The frontal process (canthus) of T. pityocampa, $T$. hellenica and T. mediterranea has five teeth, the first one is slender and longer in T. hellenica. A more developed projection is present on dorsal part of the canthus in $T$. pityocampa and T. hellenica (Fig. III, 1-3).

DNA barcoding analyses showed a great distance of the newly described species from T. pityocampa and a lower distance among themselves (Fig. IV), justifying the observation of AVTZIS et al. (2016) who reported the presence of the $T$. pityocampa ENA clade from Greece. These records should likely, but carefully, be attributed to T. hellenica, which is morphologically and genetically clearly distinguishable from $T$. mediterranea and from the former T. pityocampa ENA clade. Although T. pityocampa shows low variability from Central Italy to Spain, the barcode of a Calabrian specimens (Italy) analysed by us is very interesting. In fact, it is near T. pityocampa but clearly different $(2.05 \%)$ deserving further taxonomic studies.

Because morphological characters of Thaumetopoea females are not well studied they will be considered in future research.

\section{ACKNOWLEDGMENTS}

The authors wish to thank Prof. Christos Athanassiou (University of Thessaly, Greece), Prof. Nickolas Kavallieratos (University of Athens, Greece), Dr David Pardo Talavera (AIMPLAS, Valencia, Spain) and Prof. Santi Longo (University of Catania, Italy) for sending specimens of Thaumetopoea. We are grateful to Dr Axel Hausmann (Munich, Germany) and Dr Paul Sammut (Rabat, Malta) for comments on the manuscript. We also thank Dr Marco Infusino and Dr Silvia Greco for helping during light trapping in Calabria (Italy), Dr Carmine Ciocca and Dr Mariano Valentino for helping in field works in Molise (Italy). We are particularly grateful to Dr Paul Hebert and his team (Canadian Centre for DNA Barcoding Guelph, Canada) and to Dr Matteo Montagna (University of Milano, Italy) for DNA sequencing work. The current investigation was funded as part of the LIFE-PISA project (LIFE13 ENV/ES/000504) from European Union, and of the Project "ALForLab" (PON03PE_00024_1) co-funded by the National Operational Programme for Research and Competitiveness (PON R\&C) 2007-2013, through the
European Regional Development Fund (ERDF) and national resource [Revolving Fund - Cohesion Action Plan (CAP) MIUR].

\section{REFERENCES}

Agenjo R., 1941 - Monografia de la familia Thaumetopoeidae (Lep.). - Eos, 17: 69-130.

Avtzis D.N., PApachristos D.P., Michaelakis A., 2016 Pine processionary moths in Greece refined: introduction and population structure of Thaumetopoea pityocampa mtDNA ENA clade in Attica, Greece. - Journal of Pest Science, 89: 393-402.

DÉmolin G., 1969 - Comportement des adultes de Thaumetopoea pityocampa Schiff. Dispersion spatiale, importance écologique. - Annales des Sciences Forestieres, 26: 81-102.

Doganlar M., Avci M., 2001 - A new species of Traumatocampa Wallengren (Lepidoptera: Thaumetopoeidae) feeding on cedar from Isparta (Türkiye). Turkiye Entomoloji Dernegi, 25 (1): 19-22.

Doganlar M., Doganlar O., Doganlar F., 2005 Morphology and systematics of European species of Traumatocampa Wallengren, 1871 with descriptions of two new species from the Mediterranean region of Turkey (Lepidoptera, Thaumetopoeidae). - Entomofauna, 26 (13): 229-240.

FreinA J. DE, WitT T.J., 1982 - Taxonomische Veränderungen bei den Bombyces und Sphinges Europas und Nordwestafrikas (Lepidoptera: Thaumetopoeidae, Ctenuchidae). - Atalanta, 13 (4): 309-317.

Freina J. DE, WitT T.J., 1987 - Die Bombyces und Sphinges der Westpalaearktis (Insecta, Lepidoptera), Band 1. Edition Forshung \& Wissenchaft Verlag GmbH, München: 285-296.

HACKER H., 2016 - Systematic and illustrated catalogue of the Macroheterocera and superfamilies Cossoidea Leach, [1815], Zygaenoidea Latreille, 1809, Thyridoidea Herrich-Schäffer, 1846 and Hyblaeoidea Hampson, 1903 of the Arabian Peninsula, with a survey of their distribution (Lepidoptera). - Esperiana, 20, 147-149.

HaJiBABAeI M., JANZEN D.H., BuRnS J.M., Hallwachs W., HEBERT P.D.N., 2006 - DNA barcodes distinguish species of tropical Lepidoptera. - PNAS 2006, 103: 968-971.

Kerdelhué C., Zane L., Simonato M., Salvato P., Rousselet J., RoQues A., BATTISTI A., 2009 - Quaternary history and contemporary patterns in a currently expanding species. - BMC Evolutionary Biology, 9: 220. Doi: 10.1186/1471-2148-9-220.

KIRIAKOFF S.G., 1970 - Lepidoptera Familia Thaumetopoeidae. In: Wytsman P., editor. Genera Insectorum. SPRL Mercurius, Anvers: 1-54.

Kiriakoff S.G., TALHouK A.S., 1975 - Thaumetopoea libanotica spec. nov. (Lepidoptera: Thaumetopoeidae). Opuscola Zoologica, 137: 1-5.

Milani N., 1990 - The temperature of the egg masses of Thaumetopoea pityocampa (Den. \& Schiff.) (Lepidoptera, Thaumetopoeidae). - Redia, 73: 149-161.

Mokhefi el M., Kerdelhué C., Burban C., Battisti A., Gahdab Chakali G., Simonato M., 2016 - Genetic differentiation of the pine processionary moth at the southern edge of its range: contrasting patterns between mitochondrial and nuclear markers. - Ecology and Evolution, 6 (13): 4274-4288.

Ratnasingham S., HeBert P.D.N., 2007 - BOLD: The 
Barcode of Life Data System (www.barcodinglife.org). Molecular Ecology Notes, 7: 355-364.

Roques A., 2015 - Processionary Moths and Climate Change: An Update - Springer, Dordrecht: 1-427.

Salvato P., Battisti A., Concato S., Masutti L., PATARNEllo T., ZANE L., 2002 - Genetic differentiation in the winter pine processionary moth (Thaumetopoea pityocampa - wilkinsoni complex), inferred by AFLP and mitochondrial DNA markers. - Molecular Ecology, 11: 2435-2444.
Simonato M., Mendel Z., Kerdelhué C., Rousselet J., Magnoux E., Salvato P., Roques A., Battisti A., Zane L., 2007 - Phylogeography of the pine processionary moth Thaumetopoea wilkinsoni in the Near East. Molecular Ecology, 16: 2273-2283.

Simonato M., Battisti A., Kerdelhué C., Burban C., Lopez-VaAmonde C., Pivotto I., Salvato P., Negrisolo E., 2013 - Host and Phenology Shifts in the Evolution of the Social Moth Genus Thaumetopoea. - PLoS ONE, 8 (2): e57192. Doi: 10.1371/journal.pone.0057192. 